\title{
PENINGKATAN MINAT BACA MURID SEKOLAH DASAR MELALUI CERITA RAKYAT TORAJA DALAM BENTUK KOMIK DENGAN MEMANFAATKAN ANAK SEBAGAI TOKOH CERITA
}

\author{
Febriany Betteng Palondongan, Nadila Ridwan, Nurhalizah \\ Pendidikan Bahasa dan Sastra Indonesia, Universitas Negeri Makassar \\ Jalan A. P. Pettarani Makassar \\ Pos El. febbets32@gmail.com
}

\begin{abstract}
Increased Interest in Reading Elementary School Student Through Toraja Folklore in Comic Form by Using The Child as A Story Character. Ability to reading of Elementary School students from several studies indicates low yield. based on research conducted PIRLS (Progress in International Reading Literancy Study) in 2011 showed interest in reading Elementary School students in Indonesia ranked 41 of 45 countries. This study aims to increase interest in reading through Toraja folklore in the form of comic media, and can grow the character of children through the storyline that exiat in comic. This research is designed by using Classroom Action Reseach Method with the subject of Class V Elementary School in Rantepao Toraja Utara and the object of this research is folklore in the form of comics. Data collection is done through test and observations and analyzed by using descriptive quatitative analysis techniques. After learning by using comic media, pretest and posttest results, showed significant differences $(p<0,05)$. seed can be conclude the use of comics media influence in improving students reading interest.
\end{abstract}

\begin{abstract}
ABSTRAK
Peningkatan Minat Baca Murid Sekolah Dasar Melalui Cerita Rakyat Toraja dalam Bentuk Komik dengan Memanfaatkan Anak sebagai Tokoh Cerita. Kemampuan membaca murid Sekolah Dasar dari beberapa penelitian menunjukkan hasil yang rendah. Berdasarkan penelitian yang dilakukan PIRLS (Progress in Internasional Reading Literacy Study) tahun 2011 menunjukkan minat baca murid
\end{abstract}


FON ; Jurnal Pendidikan Bahasa dan Sastra Indonesia

Volume 13 Nomor 2 Tahun 2018

Sekolah Dasar di Indonesia menduduki peringkat 41 dari 45 negara. Penelitian ini bertujuan untuk meningkatkan minat baca anak melalui cerita rakyat Toraja dalam bentuk media komik, serta dapat menumbuhkan karakter anak melalui alur cerita yang ada dalam komik. Penelitian ini didesain dengan menggunakan Penelitian Tindakan Kelas (PTK). Dengan subjek murid Sekolah Dasar kelas V di Rantepao,Toraja Utara dan objek penelitian ini adalah cerita rakyat dalam bentuk komik. Pengumpulan data dilakukan melalui tes dan observasi serta dianalisis dengan menggunakan teknik analisis deskriptif kualitatif. Setelah melakukan pembelajaran dengan menggunakan media komik, hasil pretest dan posttest, menunjukkan perbedaan yang signifikan $(\mathrm{p}<0,05)$. Sehingga dapat disimpulkan penggunaan media komik berpengaruh dalam meningkatkan minat baca murid.

Kata Kunci: cerita rakyat, komik, minat baca.

\section{PENDAHULUAN}

Membaca merupakan alternatif model pembelajaran (learning program) yang efektif, yaitu untuk mencapai tujuan pembelajaran dari seseorang tidak tahu menjadi tahu. Membaca juga merupakan alternatif terbaik untuk mendapatkan informasi sebagai model belajar. Hasil penelitian yang dilakukan PIRLS (Progress in Internasional Reading Literacy Study) tahun 2011 menunjukkan bahwa minat baca murid Sekolah Dasar di Indonesia sangat rendah. Hal ini dibuktikan dari skor yang diperoleh yaitu 428 dan menduduki peringkat 41 dari 45 negara (Mullis, Martin, Foy, dan Drucker, 2012). Dengan kondisi seperti itu maka tak heran kualitas pendidikan di Indonesia rendah. Melihat kenyataan tersebut, bahwa tidak semua orang gemar membaca, menjadikan suatu tantangan bagi kita untuk menjadikan kegiatan membaca menjadi sebuah kegiatan yang menarik dan rutin dalam agenda seharihari. Membaca akan menjadi menarik apabila orang memahami hakikat membaca, manfaatnya serta metode yang tepat dalam pengajaran membaca.

Sumber belajar saat ini lebih banyak berupa textbook, meskipun sudah ada variasi penambahan ilustrasi tetapi belum memberikan pengaruh yang cukup terhadap peningkatan minat baca anak. Minat membaca yang rendah menyebabkan keaktifan dan hasil belajar menjadi rendah. Anak cenderung tertarik membaca buku cerita bergambar seperti komik. Karena komik memiliki alur cerita 
FON ; Jurnal Pendidikan Bahasa dan Sastra Indonesia Volume 13 Nomor 2 Tahun 2018

yang runtut dan teratur sehingga dengan judul penelitian "Pengembangan memudahkan anak untuk mengingat cerita yang telah dibacanya.

Berdasarkan observasi awal yang dilakukan peneliti menunjukkan bahwa kondisi anak pada zaman sekarang ini khususnya di Rantepao, Kabupaten Toraja Utara, Provinsi Sulawesi Selatan, pengetahuan mereka mengenai cerita rakyat Toraja sangatlah minim. Salah satu faktor penyebab terjadinya hal tersebut yakni kurangnya tradisi lisan dari orang tua untuk menceritakan kembali ceritacerita rakyat Toraja kepada anak-anaknya.

Dari sinilah muncul gagasan untuk menggabungkan antara daya tarik komik, dengan buku “Ulelean Parena Toraya (Cerita Rakyat Toraja)” karya Junus B. Lebang (2010) yang berbentuk textbook sehingga murid tertarik untuk membacanya. Kelebihan dari komik ini ialah memanfaatkan anak sebagai objek gambar dalam komik. Komik ini dibuat untuk meningkatkan minat baca anak mengenai cerita rakyat Toraja yang mengandung nilai moral yang dapat membentuk karakter anak.

Beberapa penelitian yang relevan dengan peningkatan minat baca anak dengan menggunakan media komik pernah dilakukan oleh Alfiyani (2015) Media Pembelajaran dalam Bentuk Komik pada Mata Pelajaran IPS Sub Pokok Bahasan Detik-Detik Proklamasi Kemerdekaan Republik Indonesia untuk Kelas V SD”. Hasil penelitian ini menunjukkan bahwa media pembelajaran berbentuk komik yang telah dibuat dikategorikan baik karena telah memenuhi tiga kriteria yaitu valid, praktis, dan evektif. Penelitian ini memiliki persamaan dan perbedaan dengan penelitian tersebut. Persamaannya adalah penelitian ini dengan penelitian yang dilakukan oleh Alfiyani sama-sama menggunakan media komik. Perbedaannya adalah penelitian ini membahas cerita rakyat sedangkan penelitian yang dilakukan oleh Alfiyani membahas tentang detik-detik proklamasi kemerdekaan Republik Indonesia. Adapun penelitian yang relevan dengan peningkatan minat baca anak pernah dilakukan oleh Santoso (2008) dengan judul penelitian "Membangun Minat Baca Anak Usia Dini Melalui Penyediaan Buku Bergambar". Hasil penelitian ini menunjukkan bahwa untuk anak usia sekolah dasar kelas rendah, gambar berperan penting dalam proses belajar membaca dan menulis serta pembinaan minat baca pada usia dini akan lebih efektif bila orang tua berperan serta secara 
FON ; Jurnal Pendidikan Bahasa dan Sastra Indonesia

Volume 13 Nomor 2 Tahun 2018

aktif dalam mendorong, membimbing anaknya untuk gemar membaca.

\section{METODE}

Jenis penelitian yang digunakan yaitu penelitian tindakan kelas. Penelitian tindakan kelas merupakan suatu pencermatan terhadap kegiatan yang sengaja dimunculkan, dan terjadi dalam sebuah kelas (Arikunto, 2006:91). Penelitian ini merupakan proses investigasi terkendali untuk menemukan dan memecahkan masalah pembelajaran di kelas, proses pemecahan masalah dilakukan secara bersiklus dengan tujuan untuk meningkatkan kualitas pembelajaran dan hasil pembelajaran di kelas tertentu.

Penelitian ini merupakan kaloborasi antara peneliti dengan guru kelas Sekolah Dasar. Peneliti sebagai pengamat, sedangkan yang melaksanakan adalah guru kelas. Penelitian ini dimaksudkan untuk meningkatkan minat baca murid Sekolah Dasar.

1. Penelitian ini dilakukan di SD Kristen Rrantepao 5. Dengan menyesuaikan kalender pendidikan sekolah tersebut.

2. Penelitian tindakan kela

dilaksanakan dalam kurun waktu empat bulan. Kurun waktu empat bulan tersebut digunakan oleh peneliti untuk melakukan observasi guna mengetahui kemampuan awal keterampilan membaca murid, melakukan perencanaan (menyusun RKH, menyiapkam media komik, dan menyiapkan instrumen penelitianj), pelaksanaan tindakan penelitian, melakukan pengamatan dan refleksi.

Subjek penelitian ini adalah murid Sekolah Dasar kelas IV di SD Krisrten Rantepao 5 dan objek penelitian ini adalah cerita rakyat dalam bentuk komik.

Jenis penelitian ini adalah penelitian tindakan kelas yang dilakukan secara kolaboratif. Dalam penelitian kolaboratif pihak yang melakukan tindakan adalah guru itu sendiri sedangkan yang diminta melakukan pengamatan terhadap berlangsungnya proses tindakan adalah peneliti. Menurut Kemmis dan Teggart (Wiraatmadja, 2005) ada beberapa tahapan dalam penelitian ini, yaitu:

\section{Perencanaan (plan)}

a. Peneliti membuat lima Rencana Kegiatan Harian (RKH) untuk lima kali pertemuan dengan Tema Cerita Rakyat. RKH memuat bacaan berupa teks, serta media komik untuk meningkatkan keterampilan membaca murid. 
b. Peneliti menyiapkan lima buah c. Langkah ketiga, melaksanakan cerita rakyat dalam bentuk teks dan lima pembelajaran melalui media komik yang buah komik dengan tema cerita rakyat dilakukan oleh guru yang memanfaatkan untuk kegiatan keterampilan membaca. murid sebagai tokoh cerita rakyat.

Cerita rakyat digambarkan dalam bentuk komik dan menjadikan anak sebagai tokoh cerita.

c. Peneliti menyiapkan instrumen penelitian dalam bentuk pernyataan yang terdapat empat jawaban dan murid memilih satu jawaban dari keempat pilihan.

\section{Tindakan (act)}

Guru merupakan pelaksana tindakan. Tindakan penelitian dilaksanakan di dalam kelas pada saat kegiatan inti selama 30 menit.

Langkah-langkah tindakan yang dilaksanakan pada penelitian siklus I akan dilaksanakan dalam lima pertemuan, terdiri dari:

a. Langkah pertama, guru menarik perhatian dan minat murid melalui media komik dengan mengajak murid untuk menyanyikan lagu daerah Toraja.

b. Langkah kedua, mengomunikasikan tujuan yang ingin dicapai melalui media komik. Guru menyampaikan secara langsung kepada murid bahwa tujuan kegiatan dengan menggunakan komik adalah untuk meningkatkan kemampuan membaca murid.

\section{Pengamatan (observe)}

Pengamatan dilakukan oleh tiga orang peneliti. Pengamatannya dilaksanakan dengan memperhatikan masing-masing murid yang diberikan kesempatan untuk menjadi tokoh dalam cerita rakyat.

\section{Refleksi (reflect)}

Tahap refleksi dilakukan dengan menganalisis hasil instrumen pretest dan postest penggunaan media komik. Selain menganalisis hasil instrumen, juga dilakukan analisis beberapa kelemahan dan kekuurangan selama proses pembelajaran. Hasil-hasil yang diperoleh dan permasalahan yang muncul pada pelaksanaan tindakan dijadikan sebagai dasar untuk melakukan perencanaan ulang pada siklus ke-II untuk mencapai hasil yang diinginkan. Refleksi dilakukan melalui siklus dengan guru.

Dalam penelitian ini dilakukan dalam satu siklus. Siklus diberikan apabila kondisi kelas sudah stabil dalam hal ini guru sudah mampu menguasai keterampilan membaca serta data yang ditampilkan di kelas sudah jenuh dalam arti sudah ada peningkatan keaktifan dan 
FON ; Jurnal Pendidikan Bahasa dan Sastra Indonesia

Volume 13 Nomor 2 Tahun 2018

prestasi belajar murid (Wiriaatmadja,

a) Murid membaca secara individu

2005:103).

b) Guru memberi penekanan dari

1. Tahapan Penelitian Siklus I

a. Perencanaan

Pada tahap ini peneliti mempersiapkan cerita rakyat dalam teks, silabus, rencana pelaksanaan pembelajaran, hand out, lembar kerja murid, lembar obeservasi keaktifan, lembar angket respon murid, lembar observasi pelaksanaan pembelajaran komik dan pedoman wawancara yang kemudian dikonsultasikan dengan dosen pembimbing.

b. Tindakan

Pelaksanaan tindakan pada siklus pertama dilakukan dalam tiga kali pertemuan. Tahap tindakan dilakukan oleh guru dengan menerapkan komik sebagai media pembelajaran. Proses pembelajaran dilakukan sesuai dengan jadwal pelajaran bahasa Indonesia. Materi yang akan diberikan adalah materi tentang cerita rakyat.

Adapun tindakan yang pada tiap siklus yaitu:

\section{1) Pendahuluan}

Guru menyampaikan prestasi kelas dengan memberikan apersepsi dan motivasi kepada murid dalam mempelajari materi himpunan.

2) Kegiatan Inti hasil membaca

c) Murid mengerjakan kuis secara individu

d) Peningkatan nilai

e) Pemberian penghargaan hasil belajar

3) Penutup

Guru memberikan penghargaan kepada murid yang telah berhasil mencapai kriteria keberhasilan tertentu

c. Observasi

Dilakukan selama proses pembelajaran dengan menggunakan lembar observasi yang telah disiapkan dan mencatat kejadian-kejadian yang tidak terdapat dalam lembar observasi dengan membuat lembar catatan lapangan. Halhal yang diamati selama proses pembelajaran dan aktivitas guru maupun murid selama proses pembelajaran.

d. Refleksi

Pada tahapan ini peneliti bersama guru melakukan evaluasi dari pelaksanaan tindakan pada siklus I yang digunakan sebagai bahan pertimbangan pembelajaran siklus berikutnya. Jika hasil yang diharapkan belum tercapai maka dilakukan perbaikan dan dilaksanakan pada siklus kedua.

2. Tahapan Penelitian Siklus II 
Rencana tindakan siklus II sistematis. Observasi non sistematik dimaksudkan sebagai hasil refleksi dan dilakukan dengan tidak menggunakan perbaikan terhadap pelaksanaan instrumen pengamatan sedangkan pembelajaran pada siklus I. observasi sistematik dilakukan dengan menggunakan pedoman sebagai instrumen

Teknik pengumpulan data yang dipilih sesuai dengan keadaan yang ada padakondisi lingkungan penelitian. Menurut Arikunto (1998:222), metode pengumpulan data dilakukan dengan berbagai hal, yaitu tes, angket atau kuesioner, interview, observasi, skala bertingkat dan dokumentasi. Dalam penelitian ini memilih dua metode pengumpulan data yang digunakan untuk mengetahui keterampilan membaca cerita rakyat pada murid sebagai berikut.

1. Tes

Tes yang digunakan berupa tes individu. Fungsinya untuk mengetahui sejauh mana tingkat keterampilan membaca murid yang dilakukan di akhir pembelajaran. Tes ini dilengkapi dengan format penilaian yang disesuaikan dengan kompetensi yang akan diraih setelah melakukan pembelajaran.

\section{Observasi}

Menurut Arikunto (2006:157) observasi dapat dilakukan dengan dua cara yaitu observasi non sistematis dan observasi pengamatan. Penelitian ini menggunakan observasi sistematik dimana pengamat atau peneliti membuat instrumen penelitian yang terdiri dari 30 pernyataan dengan empat jawaban dan siswa diminta untuk memilih salah satu jawaban dari keempat pilihan jawaban.

Instrumen pengumpulan data adalah alat bantu yang dipilih dan digunakan oleh peneliti dalam kegiatannya mengumpulkan data agar kegiatan tersebut menjadi sitematis dan dipermudah olehnya (Arikunto, 2005:101).

Instrumen yang digunakan, yaitu:

1. Instrumen pretest sebelum penggunaan media komik

2. Instrumen posttest sesudah penggunaan media komik

Instrument tersebut digunakan untuk mengukur minat baca murid seberapa banyak buku yang sudah murid baca, apa jenis bacaan yang murid senangi, dan bagaimana murid memanfaatkan bacaan setelah mereka membaca. Hasil dari instrument ini akan menunjukkan 
FON ; Jurnal Pendidikan Bahasa dan Sastra Indonesia

Volume 13 Nomor 2 Tahun 2018

peningkatan sebelum melakukan mentabulasi data berdasarkan variabel dari penelitian dan setelah melakukan seluruh responden, menyajikan data tiap penelitian. variabel yang diteliti, melakukan perhitungan untuk menjawab rumusan Analisis data adalah mengubah data masalah, dan melakukan perhitungan mentah menjadi data yang bermakna dan untuk menguji hipotesis yang telah mengarah pada kesimpulan ( Arikunto, diajukan (Sugiyono, 2016).Penelitian ini 2010: 53). Kegiatan dalam menganalisis menggunakan teknik analisis deskripsi data adalah: mengelompokkan data inferensial dengan melakukan uji-t. berdasarkan variabel dan jenis responden,

HASIL DAN PEMBAHASAN

\section{Hasil}

\section{Analisis Minat Baca Sebelum Penggunaan Komik}

Berikut tabel hasil analisis minat baca sesudah penggunaan komik:

Tabel 1. Minat Baca Sebelum Penggunaan Komik

\begin{tabular}{|c|c|c|c|c|c|c|c|c|c|c|}
\hline \multirow{3}{*}{$\begin{array}{l}\mathrm{N} \\
\mathrm{O}\end{array}$} & \multirow{3}{*}{$\begin{array}{l}\text { PERNYATAA } \\
\mathrm{N}\end{array}$} & \multicolumn{8}{|c|}{ JAWABAN } & \multirow{3}{*}{$\begin{array}{c}\text { JUML } \\
\text { AH }\end{array}$} \\
\hline & & \multicolumn{2}{|c|}{ SS } & \multicolumn{2}{|c|}{$S$} & \multicolumn{2}{|c|}{ TS } & \multicolumn{2}{|c|}{ STS } & \\
\hline & & $f$ & $\%$ & $f$ & $\%$ & $f$ & $\%$ & $f$ & $\%$ & \\
\hline 1 & $\begin{array}{l}\text { Saya termasuk } \\
\text { kriteria orang } \\
\text { yang suka } \\
\text { membaca. }\end{array}$ & 24 & $\begin{array}{l}61, \\
54\end{array}$ & 14 & $\begin{array}{l}35, \\
90\end{array}$ & 1 & $\begin{array}{c}2,5 \\
6\end{array}$ & 0 & 0 & $100 \%$ \\
\hline 2 & $\begin{array}{l}\text { Membaca } 1 \\
\text { buku } 1 \text { hari. }\end{array}$ & 16 & $\begin{array}{l}41, \\
03\end{array}$ & 21 & $\begin{array}{l}53 \\
85\end{array}$ & 1 & $\begin{array}{c}2,5 \\
6\end{array}$ & 1 & 2,56 & $100 \%$ \\
\hline 3 & $\begin{array}{l}\text { Membaca } 2 \\
\text { sampai } 3 \text { buku } \\
\text { dalam satu }\end{array}$ & 16 & $\begin{array}{l}41, \\
03\end{array}$ & 12 & $\begin{array}{l}30 \\
77\end{array}$ & 9 & $\begin{array}{l}23, \\
08\end{array}$ & 2 & 5,13 & $100 \%$ \\
\hline
\end{tabular}




\begin{tabular}{|c|c|c|c|c|c|c|c|c|c|c|}
\hline & minggu. & & & & & & & & & \\
\hline 4 & $\begin{array}{l}\text { Membaca } \\
\text { buku sampai } \\
\text { selesai. }\end{array}$ & 26 & $\begin{array}{l}66, \\
67\end{array}$ & 11 & $\begin{array}{l}28, \\
21\end{array}$ & 2 & $\begin{array}{c}5,1 \\
3\end{array}$ & 0 & 0 & $100 \%$ \\
\hline 5 & $\begin{array}{l}\text { Membaca } \\
\text { ulang buku } \\
\text { yang disukai. }\end{array}$ & 19 & $\begin{array}{l}48, \\
72\end{array}$ & 20 & $\begin{array}{l}51, \\
28\end{array}$ & 0 & 0 & 0 & 0 & $100 \%$ \\
\hline 6 & $\begin{array}{l}\text { Mencari bahan } \\
\text { bacaan di } \\
\text { perpustakaan } \\
\text { khususnya } \\
\text { buku berisikan } \\
\text { kumpulan } \\
\text { cerita pendek } \\
\text { dan komik. }\end{array}$ & 18 & $\begin{array}{l}46, \\
15\end{array}$ & 14 & $\begin{array}{l}35 \\
90\end{array}$ & 6 & $\begin{array}{l}15 \\
38\end{array}$ & 1 & 2,56 & $100 \%$ \\
\hline 7 & $\begin{array}{l}\text { Lebih suka } \\
\text { membaca } \\
\text { buku cerita } \\
\text { dibanding } \\
\text { buku } \\
\text { pelajaran. }\end{array}$ & 1 & $\begin{array}{c}2,5 \\
6\end{array}$ & 3 & $\begin{array}{c}7,6 \\
9\end{array}$ & 17 & $\begin{array}{l}43 \\
59\end{array}$ & 18 & $\begin{array}{c}46,1 \\
5\end{array}$ & $100 \%$ \\
\hline 8 & $\begin{array}{l}\text { Membaca } \\
\text { buku yang } \\
\text { disukai pada } \\
\text { jam pelajaran. }\end{array}$ & 6 & $\begin{array}{l}15 \\
38\end{array}$ & 3 & $\begin{array}{c}7,6 \\
9\end{array}$ & 21 & $\begin{array}{l}53 \\
85\end{array}$ & 9 & $\begin{array}{c}23,0 \\
8\end{array}$ & $100 \%$ \\
\hline 9 & $\begin{array}{l}\text { Lebih suka } \\
\text { membaca } \\
\text { daripada } \\
\text { jalan-jalan }\end{array}$ & 7 & $\begin{array}{l}17 \\
95\end{array}$ & 19 & $\begin{array}{l}48, \\
72\end{array}$ & 7 & $\begin{array}{l}17, \\
95\end{array}$ & 6 & $\begin{array}{c}15,3 \\
8\end{array}$ & $100 \%$ \\
\hline
\end{tabular}




\begin{tabular}{|c|c|c|c|c|c|c|c|c|c|c|}
\hline & $\begin{array}{l}\text { dan } \\
\text { berolahraga. }\end{array}$ & & & & & & & & & \\
\hline 10 & $\begin{array}{l}\text { Membaca } \\
\text { buku pada saat } \\
\text { tidak sibuk. }\end{array}$ & 32 & $\begin{array}{l}82, \\
05\end{array}$ & 6 & $\begin{array}{l}15, \\
38\end{array}$ & 1 & $\begin{array}{c}2,5 \\
6\end{array}$ & 0 & 0 & $100 \%$ \\
\hline 11 & $\begin{array}{l}\text { Membaca } \\
\text { buku pada saat } \\
\text { tidak sibuk. }\end{array}$ & 16 & $\begin{array}{l}41, \\
03\end{array}$ & 12 & $\begin{array}{r}30 \\
77\end{array}$ & 11 & $\begin{array}{l}28, \\
21\end{array}$ & 0 & 0 & $100 \%$ \\
\hline 12 & $\begin{array}{l}\text { Apabila tidak } \\
\text { ada guru yang } \\
\text { mengajar, } \\
\text { waktu luang } \\
\text { diisi dengan } \\
\text { membaca } \\
\text { buku }\end{array}$ & 16 & $\begin{array}{l}41, \\
03\end{array}$ & 21 & $\begin{array}{l}53 \\
85\end{array}$ & 1 & $\begin{array}{c}2,5 \\
6\end{array}$ & 1 & 2,56 & $100 \%$ \\
\hline 13 & $\begin{array}{l}\text { Saya suka } \\
\text { membaca } \\
\text { buku fiksi } \\
\text { (buku cerita, } \\
\text { komik, } \\
\text { kumpulan } \\
\text { dongeng dan } \\
\text { novel). }\end{array}$ & 21 & $\begin{array}{l}53, \\
85\end{array}$ & 13 & $\begin{array}{r}33 \\
33\end{array}$ & 3 & $\begin{array}{c}7,6 \\
9\end{array}$ & 2 & 5,13 & $100 \%$ \\
\hline 14 & $\begin{array}{l}\text { Saya suka } \\
\text { membaca } \\
\text { buku non-fiksi } \\
\text { (buku } \\
\text { pelajaran, } \\
\text { biografi, buku }\end{array}$ & 18 & $\begin{array}{l}46, \\
15\end{array}$ & 20 & $\begin{array}{l}51, \\
28\end{array}$ & 1 & $\begin{array}{c}2,5 \\
6\end{array}$ & 0 & 0 & $100 \%$ \\
\hline
\end{tabular}


FON ; Jurnal Pendidikan Bahasa dan Sastra Indonesia

Volume 13 Nomor 2 Tahun 2018

\begin{tabular}{|c|c|c|c|c|c|c|c|c|c|c|}
\hline & ensiklopedia). & & & & & & & & & \\
\hline 15 & $\begin{array}{l}\text { Saya suka } \\
\text { membaca } \\
\text { koran/majalah. }\end{array}$ & 3 & $\begin{array}{c}7,6 \\
9\end{array}$ & 14 & $\begin{array}{l}35 \\
90\end{array}$ & 16 & $\begin{array}{l}41, \\
03\end{array}$ & 6 & $\begin{array}{c}15,3 \\
8\end{array}$ & $100 \%$ \\
\hline 16 & $\begin{array}{l}\text { Saya membaca } \\
\text { buku di } \\
\text { perpustakaan } \\
\text { dalam } \\
\text { seminggu. }\end{array}$ & 11 & $\begin{array}{l}28 \\
21\end{array}$ & 21 & $\begin{array}{l}53, \\
85\end{array}$ & 5 & $\begin{array}{l}12, \\
82\end{array}$ & 2 & 5,13 & $100 \%$ \\
\hline 17 & $\begin{array}{l}\text { Saya membeli } \\
\text { buku satu kali } \\
\text { dalam satu } \\
\text { bulan. }\end{array}$ & 3 & $\begin{array}{c}7,6 \\
9\end{array}$ & 18 & $\begin{array}{l}46, \\
15\end{array}$ & 16 & $\begin{array}{l}41, \\
03\end{array}$ & 2 & 5,13 & $100 \%$ \\
\hline 18 & $\begin{array}{l}\text { Saya suka } \\
\text { meminjam } \\
\text { buku teman. }\end{array}$ & 2 & $\begin{array}{c}5,1 \\
3\end{array}$ & 21 & $\begin{array}{l}53 \\
85\end{array}$ & 7 & $\begin{array}{l}17, \\
95\end{array}$ & 9 & $\begin{array}{c}23,0 \\
8\end{array}$ & $100 \%$ \\
\hline 19 & $\begin{array}{l}\text { Membaca } \\
\text { merupakan } \\
\text { kegiatan yang } \\
\text { berat. }\end{array}$ & 2 & $\begin{array}{c}5,1 \\
3\end{array}$ & 1 & $\begin{array}{c}2,5 \\
6\end{array}$ & 8 & $\begin{array}{l}20, \\
51\end{array}$ & 28 & $\begin{array}{c}71,7 \\
9\end{array}$ & $100 \%$ \\
\hline 20 & $\begin{array}{l}\text { Membaca } \\
\text { merupakan } \\
\text { kegiatan yang } \\
\text { mebuang- } \\
\text { buang waktu. }\end{array}$ & 1 & $\begin{array}{c}2,5 \\
6\end{array}$ & 1 & $\begin{array}{c}2,5 \\
6\end{array}$ & 10 & $\begin{array}{l}25, \\
64\end{array}$ & 27 & $\begin{array}{c}69,2 \\
3\end{array}$ & $100 \%$ \\
\hline 21 & $\begin{array}{l}\text { Membaca } \\
\text { merupakan } \\
\text { kegiatan yang }\end{array}$ & 1 & $\begin{array}{c}2,5 \\
6\end{array}$ & 0 & 0 & 10 & $\begin{array}{l}25, \\
64\end{array}$ & 28 & $\begin{array}{c}71,7 \\
9\end{array}$ & $100 \%$ \\
\hline
\end{tabular}




\begin{tabular}{|c|c|c|c|c|c|c|c|c|c|c|}
\hline & membosankan. & & & & & & & & & \\
\hline 22 & $\begin{array}{l}\text { Membaca } \\
\text { merupakan } \\
\text { kegiatan yang } \\
\text { menyenangkan }\end{array}$ & 32 & $\begin{array}{l}82, \\
05\end{array}$ & 6 & $\begin{array}{l}15 \\
38\end{array}$ & 0 & 0 & 1 & 2,56 & $100 \%$ \\
\hline 23 & $\begin{array}{l}\text { Membaca } \\
\text { merupakan } \\
\text { kegiatan yang } \\
\text { penting. }\end{array}$ & 29 & $\begin{array}{l}74, \\
36\end{array}$ & 9 & $\begin{array}{l}23 \\
08\end{array}$ & 1 & $\begin{array}{c}2,5 \\
6\end{array}$ & 0 & 0 & $100 \%$ \\
\hline 24 & $\begin{array}{l}\text { Saya membaca } \\
\text { buku karena } \\
\text { disuruh orang } \\
\text { tua. }\end{array}$ & 6 & $\begin{array}{l}15 \\
28\end{array}$ & 11 & $\begin{array}{l}28 \\
21\end{array}$ & 13 & $\begin{array}{l}33, \\
33\end{array}$ & 9 & $\begin{array}{c}23,0 \\
8\end{array}$ & $100 \%$ \\
\hline 25 & $\begin{array}{l}\text { Saya membaca } \\
\text { buku karena } \\
\text { disuruh guru. }\end{array}$ & 8 & $\begin{array}{l}20, \\
51\end{array}$ & 16 & $\begin{array}{l}41, \\
03\end{array}$ & 9 & $\begin{array}{l}23, \\
08\end{array}$ & 6 & $\begin{array}{c}15,3 \\
8\end{array}$ & $100 \%$ \\
\hline 26 & $\begin{array}{l}\text { Saya membaca } \\
\text { buku } \\
\text { berdasarkan } \\
\text { inisiatif } \\
\text { sendiri. }\end{array}$ & 20 & $\begin{array}{l}51, \\
28\end{array}$ & 15 & $\begin{array}{l}38, \\
46\end{array}$ & 3 & $\begin{array}{c}7,6 \\
9\end{array}$ & 1 & 2,56 & $100 \%$ \\
\hline 27 & $\begin{array}{l}\text { Saya membaca } \\
\text { buku bersama } \\
\text { orang tua. }\end{array}$ & 16 & $\begin{array}{l}41, \\
03\end{array}$ & 17 & $\begin{array}{l}43, \\
59\end{array}$ & 6 & $\begin{array}{l}15 \\
28\end{array}$ & 0 & 0 & $100 \%$ \\
\hline 28 & $\begin{array}{l}\text { Saya membaca } \\
\text { buku bersama } \\
\text { teman-teman. }\end{array}$ & 27 & $\begin{array}{l}69, \\
23\end{array}$ & 11 & $\begin{array}{l}28, \\
21\end{array}$ & 0 & 0 & 1 & 2,56 & $100 \%$ \\
\hline
\end{tabular}


FON ; Jurnal Pendidikan Bahasa dan Sastra Indonesia

Volume 13 Nomor 2 Tahun 2018

\begin{tabular}{|l|l|c|c|c|c|c|c|c|c|c|}
\hline 29 & 12 & 30, & 23 & 58, & 3 & 7,6 & 1 & 2,56 & $100 \%$ \\
& $\begin{array}{l}\text { Saya } \\
\text { menceritakan } \\
\text { isi buku yang } \\
\text { saya baca } \\
\text { kepada teman- } \\
\text { teman saya. }\end{array}$ & 77 & 97 & 9 & & & & & & \\
\hline 30 & $\begin{array}{l}\text { Saya } \\
\text { menceritakan } \\
\text { isi buku yang } \\
\text { saya baca } \\
\text { kepada orang } \\
\text { tua/saudara } \\
\text { saya. }\end{array}$ & 90 & 14 & 35, & 54, & 2 & 5,1 & 1 & 2,56 & $100 \%$ \\
\end{tabular}

Hasil analisis di atas menunjukkan pada Setuju. Dan hasil analisis yang memiliki pernyataan yang memiliki hasil terendah hasil tertinggi yaitu pada pernyataan yaitu pada pernyataan "Membaca "Membaca merupakan kegiatan yang merupakan kegiatan yang membosankan”. menyenangkan”. Murid yang memilih Nilai jawaban terendah yaitu 0 karena jawaban Sangat Setuju sebanyak 32 orang. tidak ada murid yang memilih Sangat

\section{Analisis Minat Baca Sesudah Penggunaan Komik}

Berikut tabel hasil analisis minat baca sesudah penggunaan komik:

Tabel 2. Minat Baca Setelah Penggunaan Komik

\begin{tabular}{|c|c|c|c|c|c|c|c|c|c|c|}
\hline \multirow{3}{*}{$\begin{array}{l}\mathrm{N} \\
\mathrm{O}\end{array}$} & \multirow{3}{*}{$\begin{array}{c}\text { PERNYATAA } \\
\mathrm{N}\end{array}$} & \multicolumn{8}{|c|}{ JAWABAN } & \multirow{3}{*}{$\begin{array}{c}\text { JUML } \\
\text { AH }\end{array}$} \\
\hline & & \multicolumn{2}{|c|}{ SS } & \multicolumn{2}{|c|}{$S$} & \multicolumn{2}{|c|}{ TS } & \multicolumn{2}{|c|}{ STS } & \\
\hline & & $f$ & $\%$ & $f$ & $\%$ & $f$ & $\%$ & $\%$ & $\%$ & \\
\hline 1 & $\begin{array}{l}\text { Saya termasuk } \\
\text { kriteria orang }\end{array}$ & 24 & 61 , & 14 & 35 , & 1 & 2,5 & 0 & 0 & $100 \%$ \\
\hline
\end{tabular}


FON ; Jurnal Pendidikan Bahasa dan Sastra Indonesia

Volume 13 Nomor 2 Tahun 2018

\begin{tabular}{|c|c|c|c|c|c|c|c|c|c|c|}
\hline & yang suka & & 54 & & 90 & & 6 & & & \\
\hline 2 & $\begin{array}{l}\text { Membaca } 1 \\
\text { buku } 1 \text { hari. }\end{array}$ & 16 & $\begin{array}{l}41, \\
03\end{array}$ & 21 & $\begin{array}{l}53, \\
85\end{array}$ & 1 & $\begin{array}{c}2,5 \\
6\end{array}$ & 1 & 2,56 & $100 \%$ \\
\hline 3 & $\begin{array}{l}\text { Membaca } 2 \\
\text { sampai } 3 \text { buku } \\
\text { dalam satu } \\
\text { minggu. }\end{array}$ & 16 & $\begin{array}{l}41, \\
03\end{array}$ & 12 & $\begin{array}{r}30, \\
77\end{array}$ & 9 & $\begin{array}{l}23, \\
08\end{array}$ & 2 & 5,13 & $100 \%$ \\
\hline 4 & $\begin{array}{l}\text { Membaca } \\
\text { buku sampai } \\
\text { selesai. }\end{array}$ & 26 & $\begin{array}{l}66, \\
67\end{array}$ & 11 & $\begin{array}{l}28, \\
21\end{array}$ & 2 & $\begin{array}{c}5,1 \\
3\end{array}$ & 0 & 0 & $100 \%$ \\
\hline 5 & $\begin{array}{l}\text { Membaca } \\
\text { ulang buku } \\
\text { yang disukai. }\end{array}$ & 19 & $\begin{array}{l}48, \\
72\end{array}$ & 20 & $\begin{array}{l}51, \\
28\end{array}$ & 0 & 0 & 0 & 0 & $100 \%$ \\
\hline 6 & $\begin{array}{l}\text { Mencari bahan } \\
\text { bacaan di } \\
\text { perpustakaan } \\
\text { khususnya } \\
\text { buku berisikan } \\
\text { kumpulan } \\
\text { cerita pendek } \\
\text { dan komik. }\end{array}$ & 18 & $\begin{array}{l}46, \\
15\end{array}$ & 14 & $\begin{array}{l}35, \\
90\end{array}$ & 6 & $\begin{array}{l}15, \\
38\end{array}$ & 1 & 2,56 & $100 \%$ \\
\hline 7 & $\begin{array}{l}\text { Lebih suka } \\
\text { membaca } \\
\text { buku cerita } \\
\text { dibanding } \\
\text { buku } \\
\text { pelajaran. }\end{array}$ & 1 & $\begin{array}{c}2,5 \\
6\end{array}$ & 3 & $\begin{array}{c}7,6 \\
9\end{array}$ & 17 & $\begin{array}{l}43, \\
59\end{array}$ & 18 & $\begin{array}{c}46,1 \\
5\end{array}$ & $100 \%$ \\
\hline
\end{tabular}


FON ; Jurnal Pendidikan Bahasa dan Sastra Indonesia

Volume 13 Nomor 2 Tahun 2018

\begin{tabular}{|c|c|c|c|c|c|c|c|c|c|c|}
\hline 8 & $\begin{array}{l}\text { Membaca } \\
\text { buku yang } \\
\text { disukai pada } \\
\text { jam pelajaran. }\end{array}$ & 6 & $\begin{array}{l}15, \\
38\end{array}$ & 3 & $\begin{array}{c}7,6 \\
9\end{array}$ & 21 & $\begin{array}{l}53 \\
85\end{array}$ & 9 & $\begin{array}{c}23,0 \\
8\end{array}$ & $100 \%$ \\
\hline 9 & $\begin{array}{l}\text { Lebih suka } \\
\text { membaca } \\
\text { daripada } \\
\text { jalan-jalan } \\
\text { dan } \\
\text { berolahraga. }\end{array}$ & 7 & $\begin{array}{l}17, \\
95\end{array}$ & 19 & $\begin{array}{l}48, \\
72\end{array}$ & 7 & $\begin{array}{l}\text { 17, } \\
95\end{array}$ & 6 & $\begin{array}{c}15,3 \\
8\end{array}$ & $100 \%$ \\
\hline 10 & $\begin{array}{l}\text { Membaca } \\
\text { buku pada saat } \\
\text { tidak sibuk. }\end{array}$ & 32 & $\begin{array}{l}82, \\
05\end{array}$ & 6 & $\begin{array}{l}15 \\
38\end{array}$ & 1 & $\begin{array}{c}2,5 \\
6\end{array}$ & 0 & 0 & $100 \%$ \\
\hline 11 & $\begin{array}{l}\text { Membaca } \\
\text { buku pada saat } \\
\text { tidak sibuk. }\end{array}$ & 16 & $\begin{array}{l}41, \\
03\end{array}$ & 12 & $\begin{array}{l}30 \\
77\end{array}$ & 11 & $\begin{array}{l}28 \\
21\end{array}$ & 0 & 0 & $100 \%$ \\
\hline 12 & $\begin{array}{l}\text { Apabila tidak } \\
\text { ada guru yang } \\
\text { mengajar, } \\
\text { waktu luang } \\
\text { diisi dengan } \\
\text { membaca } \\
\text { buku }\end{array}$ & 16 & $\begin{array}{l}\text { 41, } \\
03\end{array}$ & 21 & $\begin{array}{l}53, \\
85\end{array}$ & 1 & $\begin{array}{c}2,5 \\
6\end{array}$ & 1 & 2,56 & $100 \%$ \\
\hline 13 & $\begin{array}{l}\text { Saya suka } \\
\text { membaca } \\
\text { buku fiksi } \\
\text { (buku cerita, } \\
\text { komik, } \\
\text { kumpulan }\end{array}$ & 21 & $\begin{array}{l}53 \\
85\end{array}$ & 13 & $\begin{array}{l}33 \\
33\end{array}$ & 3 & $\begin{array}{c}7,6 \\
9\end{array}$ & 2 & 5,13 & $100 \%$ \\
\hline
\end{tabular}




\begin{tabular}{|c|c|c|c|c|c|c|c|c|c|c|}
\hline & $\begin{array}{l}\text { dongeng dan } \\
\text { novel). }\end{array}$ & & & & & & & & & \\
\hline 14 & $\begin{array}{l}\text { Saya suka } \\
\text { membaca } \\
\text { buku non-fiksi } \\
\text { (buku } \\
\text { pelajaran, } \\
\text { biografi, buku } \\
\text { ensiklopedia). }\end{array}$ & 18 & $\begin{array}{r}46, \\
15\end{array}$ & 20 & $\begin{array}{l}51, \\
28\end{array}$ & 1 & $\begin{array}{c}2,5 \\
6\end{array}$ & 0 & 0 & $100 \%$ \\
\hline 15 & $\begin{array}{l}\text { Saya suka } \\
\text { membaca } \\
\text { koran/majalah. }\end{array}$ & 3 & $\begin{array}{c}7,6 \\
9\end{array}$ & 14 & $\begin{array}{l}35, \\
90\end{array}$ & 16 & $\begin{array}{l}41, \\
03\end{array}$ & 6 & $\begin{array}{c}15,3 \\
8\end{array}$ & $100 \%$ \\
\hline 16 & $\begin{array}{l}\text { Saya membaca } \\
\text { buku di } \\
\text { perpustakaan } \\
\text { dalam } \\
\text { seminggu. }\end{array}$ & 11 & $\begin{array}{l}28, \\
21\end{array}$ & 21 & $\begin{array}{l}53 \\
85\end{array}$ & 5 & $\begin{array}{l}12, \\
82\end{array}$ & 2 & 5,13 & $100 \%$ \\
\hline 17 & $\begin{array}{l}\text { Saya membeli } \\
\text { buku satu kali } \\
\text { dalam satu } \\
\text { bulan. }\end{array}$ & 3 & $\begin{array}{c}7,6 \\
9\end{array}$ & 18 & $\begin{array}{r}46, \\
15\end{array}$ & 16 & $\begin{array}{c}41, \\
0\end{array}$ & 2 & 5,13 & $100 \%$ \\
\hline 18 & $\begin{array}{l}\text { Saya suka } \\
\text { meminjam } \\
\text { buku teman. }\end{array}$ & 2 & $\begin{array}{l}5,1 \\
3\end{array}$ & 21 & $\begin{array}{l}53 \\
85\end{array}$ & 7 & $\begin{array}{l}17 \\
95\end{array}$ & 9 & $\begin{array}{l}23,0 \\
8\end{array}$ & $100 \%$ \\
\hline 19 & $\begin{array}{l}\text { Membaca } \\
\text { merupakan } \\
\text { kegiatan yang } \\
\text { berat. }\end{array}$ & 2 & $\begin{array}{l}5,1 \\
3\end{array}$ & 1 & $\begin{array}{l}2,5 \\
6\end{array}$ & 8 & $\begin{array}{l}20, \\
51\end{array}$ & 28 & $\begin{array}{l}71,7 \\
9\end{array}$ & $100 \%$ \\
\hline
\end{tabular}


FON ; Jurnal Pendidikan Bahasa dan Sastra Indonesia

Volume 13 Nomor 2 Tahun 2018

\begin{tabular}{|c|c|c|c|c|c|c|c|c|c|c|}
\hline 20 & $\begin{array}{l}\text { Membaca } \\
\text { merupakan } \\
\text { kegiatan yang } \\
\text { mebuang- } \\
\text { buang waktu. }\end{array}$ & 1 & $\begin{array}{l}2,5 \\
6\end{array}$ & 1 & $\begin{array}{l}2,5 \\
6\end{array}$ & 10 & $\begin{array}{l}25, \\
64\end{array}$ & 27 & $\begin{array}{l}69,2 \\
3\end{array}$ & $100 \%$ \\
\hline 21 & $\begin{array}{l}\text { Membaca } \\
\text { merupakan } \\
\text { kegiatan yang } \\
\text { membosankan. }\end{array}$ & 1 & $\begin{array}{l}2,5 \\
6\end{array}$ & 0 & 0 & 10 & $\begin{array}{l}25, \\
64\end{array}$ & 28 & $\begin{array}{l}71,7 \\
9\end{array}$ & $100 \%$ \\
\hline 22 & $\begin{array}{l}\text { Membaca } \\
\text { merupakan } \\
\text { kegiatan yang } \\
\text { menyenangkan }\end{array}$ & 32 & $\begin{array}{l}82, \\
05\end{array}$ & 6 & $\begin{array}{l}15, \\
38\end{array}$ & 0 & 0 & 1 & 2,56 & $100 \%$ \\
\hline 23 & $\begin{array}{l}\text { Membaca } \\
\text { merupakan } \\
\text { kegiatan yang } \\
\text { penting. }\end{array}$ & 29 & $\begin{array}{l}74, \\
36\end{array}$ & 9 & $\begin{array}{l}23, \\
08\end{array}$ & 1 & $\begin{array}{l}2,5 \\
6\end{array}$ & 0 & 0 & $100 \%$ \\
\hline 24 & $\begin{array}{l}\text { Saya membaca } \\
\text { buku karena } \\
\text { disuruh orang } \\
\text { tua. }\end{array}$ & 6 & $\begin{array}{l}15 \\
38\end{array}$ & 11 & $\begin{array}{l}28, \\
21\end{array}$ & 13 & $\begin{array}{l}33 \\
33\end{array}$ & 9 & $\begin{array}{l}23,0 \\
8\end{array}$ & $100 \%$ \\
\hline 25 & $\begin{array}{l}\text { Saya membaca } \\
\text { buku karena } \\
\text { disuruh guru. }\end{array}$ & 8 & $\begin{array}{l}20, \\
51\end{array}$ & 16 & $\begin{array}{l}41, \\
03\end{array}$ & 9 & $\begin{array}{l}23 \\
08\end{array}$ & 6 & $\begin{array}{l}15,3 \\
8\end{array}$ & $100 \%$ \\
\hline 26 & $\begin{array}{l}\text { Saya membaca } \\
\text { buku } \\
\text { berdasarkan } \\
\text { inisiatif }\end{array}$ & 20 & $\begin{array}{l}51, \\
28\end{array}$ & 15 & $\begin{array}{l}38, \\
46\end{array}$ & 3 & $\begin{array}{l}7,6 \\
9\end{array}$ & 1 & 2,56 & $100 \%$ \\
\hline
\end{tabular}




\begin{tabular}{|c|c|c|c|c|c|c|c|c|c|c|}
\hline & sendiri. & & & & & & & & & \\
\hline 27 & $\begin{array}{l}\text { Saya membaca } \\
\text { buku bersama } \\
\text { orang tua. }\end{array}$ & 16 & $\begin{array}{l}41, \\
03\end{array}$ & 17 & $\begin{array}{l}43 \\
59\end{array}$ & 6 & $\begin{array}{l}15, \\
38\end{array}$ & 0 & 0 & $100 \%$ \\
\hline 28 & $\begin{array}{l}\text { Saya membaca } \\
\text { buku bersama } \\
\text { teman-teman. }\end{array}$ & 27 & $\begin{array}{l}69, \\
23\end{array}$ & 11 & $\begin{array}{l}28, \\
21\end{array}$ & 0 & 0 & 1 & 2,56 & $100 \%$ \\
\hline 29 & $\begin{array}{l}\text { Saya } \\
\text { menceritakan } \\
\text { isi buku yang } \\
\text { saya baca } \\
\text { kepada teman- } \\
\text { teman saya. }\end{array}$ & 12 & $\begin{array}{l}30 \\
77\end{array}$ & 23 & $\begin{array}{l}58, \\
97\end{array}$ & 3 & $\begin{array}{l}7,6 \\
9\end{array}$ & 1 & 2,56 & $100 \%$ \\
\hline 30 & $\begin{array}{l}\text { Saya } \\
\text { menceritakan } \\
\text { isi buku yang } \\
\text { saya baca } \\
\text { kepada orang } \\
\text { tua/saudara } \\
\text { saya. }\end{array}$ & 14 & $\begin{array}{l}35 \\
90\end{array}$ & 22 & $\begin{array}{l}56, \\
41\end{array}$ & 2 & $\begin{array}{l}5,1 \\
3\end{array}$ & 1 & 2,56 & $100 \%$ \\
\hline
\end{tabular}

Hasil analisis di atas yang menunjukkan memilih Sangat Setuju. Dan hasil analisis hasil terendah setelah melakukan yang memiliki hasil tertinggi yaitu pada penelitian yaitu pada pernyataan "Lebih pernyataan "Membaca merupakan suka membaca buku cerita dibanding kegiatan yang menyenangkan”. Murid buku pelajaran”. Nilai jawaban terendah yang memilih jawaban Sangat Setuju yaitu 0 karena tidak ada murid yang sebanyak 32 orang. 
FON ; Jurnal Pendidikan Bahasa dan Sastra Indonesia

Volume 13 Nomor 2 Tahun 2018

\section{Pengaruh Uji T antara Pretest dan Posttest}

\section{Hasil Uji Normalitas}

Tabel 3. Hasil Uji Normalitas

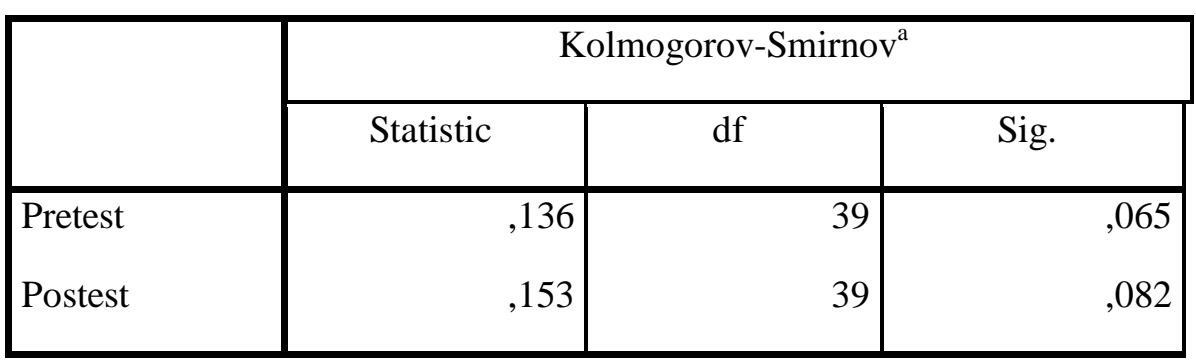

Nilai signifikansi pretest 0,065 dan nilai signifikansi posttest 0,082. Dengan demikian data disimpulkan berdistribusi normal karena nilai Signifikan >0.05. Dengan demikian data dapat dilanjutkan dengan uji $\mathrm{T}$ dengan statistik parametris

\section{Hasil Analisis Uji T}

Tabel 4. Paired Samples Statistics

\begin{tabular}{|rl|r|r|r|r|}
\hline & & \multicolumn{1}{|c|}{ Mean } & N & Std. Deviation & Std. Error Mean \\
\hline Pair 1 & Pretest & 94,36 & 39 & 8,229 & 1,318 \\
& Postest & 101,00 & 39 & 9,125 & 1,461 \\
\hline
\end{tabular}

Tabel 5. Paired Samples Correlations

\begin{tabular}{|ll|r|r|r|}
\hline & N & Correlation & \multicolumn{2}{|c|}{ Sig. } \\
\hline Pair 1 $\quad$ Pretest \& Postest & 39 &, 430 &, 006 \\
\hline
\end{tabular}


FON ; Jurnal Pendidikan Bahasa dan Sastra Indonesia

Volume 13 Nomor 2 Tahun 2018

Tabel 6. Paired Samples Test

\begin{tabular}{|c|c|c|c|c|c|c|c|c|c|}
\hline & \multicolumn{5}{|c|}{ Paired Differences } & \multirow[b]{3}{*}{$\mathrm{t}$} & \multirow[b]{3}{*}{$\mathrm{df}$} & \multirow{3}{*}{$\begin{array}{l}\text { Sig. (2- } \\
\text { tailed) }\end{array}$} \\
\hline & & \multirow[b]{2}{*}{ Mean } & \multirow{2}{*}{$\begin{array}{c}\text { Std. } \\
\text { Deviation }\end{array}$} & \multirow{2}{*}{$\begin{array}{l}\text { Std. } \\
\text { Error } \\
\text { Mean }\end{array}$} & \multicolumn{2}{|c|}{$\begin{array}{l}\text { 95\% Confidence } \\
\text { Interval of the } \\
\text { Difference }\end{array}$} & & & \\
\hline & & & & & Lower & Upper & & & \\
\hline Pair 1 & $\begin{array}{l}\text { Pretest - } \\
\text { Postest }\end{array}$ & $-6,641$ & 9,298 & 1,489 & $-9,655$ & $-3,627$ & $-4,461$ & 38 & ,000 \\
\hline
\end{tabular}

Nilai rata-rata hasil pretest 94,36 dan nilai rata-rata hasil posttest 101,00.

Berdasarkan analisis data di atas diketahui bahwa $\mathrm{t}=4,461 \quad(\mathrm{p}=0,000)$. Dengan demikian, terdapat perbedaan yang signifikan antara skor pretest dan postest ( $\mathrm{p}<0,05)$. Dari tabel di atas dapat dilihat bahwa penggunaan media komik dapat meningkatkan minat baca murid sekolah dasar. Sehingga dapat disimpulkan bahwa penggunaan media komik dapat meningkatkan minat baca anak.

\section{KESIMPULAN}

Berdasarkan hasil dan pembahasan, didapatkan kesimpulan bahwa penggunaan media komik dalam pembelajaran membaca lebih berpengaruh meningkatkan minat baca dibanding dengan pemberian teks cerita. Melalui hasil penelitian, terdapat beberapa hasil yang dicapai dari penelitian ini, yaitu menumbuhkan minat membaca di kalangan anak, membentuk karakter anak melalui pesan moral yang terdapat dalam cerita rakyat. membangkitkan kesadaran masyarakat khususnya anak tentang pentingnya melestarikan cerita rakyat, elestarikan cerita rakyat Toraja bagi generasi muda Toraja.

\section{UCAPAN TERIMA KASIH}

Penulis menyampaikan ucapan terima kasih kepada Direktorat Jenderal Pembelajaran dan Kemahasiswaan Kementrian Riset Tekhnologi dan Pendidikan Tinggi Republik Indonesia yang telah mendanai program kreativitas mahasiswa penelitian sosial humaniora ini.

\section{DAFTAR PUSTAKA}

Alfiyani, Novita. 2015. Pengembangan Media Pembelajaran dalam Bentuk 
FON ; Jurnal Pendidikan Bahasa dan Sastra Indonesia

Volume 13 Nomor 2 Tahun 2018

Komik pada Mata Pelajaran IPS

Sub Pokok Bahasan Detik-Detik

Proklamasi Kemerdekaan Republik

Indonesia untuk Kelas $V$ SD.

Jember: Universitas Jember.

Arikunto, Suharsimi. 2010. Prosedur

Penelitian, Suatu Pendekatan

Praktik. Jakarta: Rineka Cipta.

Lebang, Junus Bunga. 2006. Ulelean

Parena Toraya. Toraja: Siayoka.

Mullis , Ina V.S, Michael O. Martin,

Pierre Foy, and Kathleen T.

Drucker. 2012. PIRLS 2011

International Results in Reading.

Boston: TIMSS \& PIRLS

International Study Center,Lynch

School of Education, Boston

College.

Najah, Naqib. 2014. Suku Toraja

Fanatisme

Filosofi

Leluhur.Makassar: Arus Timur.

Rahim, Farida. 2011. Pengajaran

Membaca di Sekolah Dasar. Jakarta:

Bumi Aksara.

Santoso, Hari. 2008. Membangun Minat

Baca Anak Usia Dini melalui
Penyediaan Buku Bergambar.

Universitas Negeri Malang.

Sugihastuti. 2015. Sastra Anak: Teori dan

Apresiasi. Yogyakarta: Penerbit

Ombak.

Sugiyono. 2016. Metode Penelitian

Pendidikan (Pendekatan Kuantitatif, Kualitatif, dan R\&D). Bandung:

Alfabeta.

Tang, M. R., Jufri, dan Sultan. 2015.

Pengembangan Bahan Ajar Cerita

Fiksi Berbasis Wacana Budaya di

Sekolah Dasar. Pendidikan dan

Pembelajaran, 22 (2): 169-175.

Tang, M. R. dan Sultan. 2015.

Pengembangan Model Bahan Ajar

Membaca Sastra Berbasis Literasi

Pirls Untuk Meningkatkan

Penalaran Kritis Murid Sekolah

Dasar.Laporan Penelitian.

Makassar: Lembaga Penelitian

UNM.

Wiriaatmadja, Rochiati. 2005. Metode

Penelitian Tindakan Kelas.

Bandung: PT Remaja Rosdakary. 